\title{
Respiratory syncytial virus infections
}

\author{
P. S. GARDNER \\ Department of Virology, Royal Victoria Infirmary, Newcastle upon Tyne
}

\begin{abstract}
Summary
RS virus was isolated from $10.5 \%$ of the specimens examined in the MRC/PHLS hospital survey and from $0.9 \%$ of those in the general practice survey. The highest isolation rates were in infants with lower respiratory tract infections. Dyspnoea, wheezing and cough were the predominant clinical features. The differences in the rates between hospital and general practice and newer methods of diagnosis of $\mathbf{R S}$ virus infection are discussed.
\end{abstract}

\section{Introduction}

Although respiratory syncytial (RS) virus has been implicated in acute respiratory infection for only about 13 years, it is now known to be the principal respiratory pathogen of infants and young children. RS virus was originally found as an agent causing respiratory illness in chimpanzees (Morris, Blount \& Savage, 1956); its human connection was first noted by Chanock \& Finberg (1957). The virus produces a characteristic giant cell cytopathic effect in tissue culture which led to a change in name from 'chimpanzee coryza agent' to 'respiratory syncytial virus'. In 1960, Beem and his colleagues in Chicago demonstrated that RS virus was frequently associated with pneumonia and bronchiolitis, especially in children under 1 year of age. This work was rapidly confirmed by Chanock and his associates in Washington in 1961 and by McClelland and her colleagues in the same year in Philadelphia. All found that the most severe illnesses caused by RS virus occurred in infants and young children and the virus was seldom present in children without respiratory symptoms.

The establishment of RS virus as a major cause of acute lower respiratory illness in infants in this country was mainly the result of studies in both Manchester (Holzel et al., 1963, 1965) and in Newcastle (Andrew \& Gardner, 1963; Elderkin et al., 1965; Gardner, 1968).

Originally, difficulties were experienced in isolating RS virus, because of its extreme lability and failure to survive freezing and thawing (Beem $e t$ al., 1960). In addition, carefully selected sensitive tissue culture cell lines are required which must be maintained in media free of substances which are inhibitory for the growth of RS virus.

\section{Results}

Despite these difficulties, two surveys were set up by the M.R.C. to study the occurrence of acute respiratory virus infection in children both in hospital and in general practice; one of the purposes of these surveys was to investigate the importance of different viruses including RS virus. As far as possible, laboratory techniques were standardized but differences were bound to develop, as were other factors such as variations in media, reagents, and distances which specimens needed to be broughe from patients to the laboratory. Although the overat rate of isolation of virus in both the general prace $\vec{\varphi}$ titioner and the hospital surveys was lower thap co expected, certain facts were still evident from these studies.

\section{Hospital survey}

Isolation rate and age. RS virus was isolated from $\stackrel{\odot}{\perp}$ $10.5 \%$ of the 2418 specimens submitted for investi- $\overrightarrow{\vec{B}}$ gation. The virus was clearly shown to occur most frequently with acute respiratory illness in the youngest children. This is illustrated in Table 1.

Virus and clinical categories. RS virus has also shown a characteristic association with lower res- 3 piratory infections, especially with bronchiolitis. This is well illustrated in Table 2. For simplicity, pharyngitis, tonsillitis, otitis media and colds have of been included under the general heading of upper $₹$ respiratory tract infection. It can be seen that though $O$ bronchiolitis is frequently associated with RS virus, it is still the major pathogen in pneumonia, bronchitis and upper respiratory tract infection for the youngest age groups.

Epidemics. RS virus occurs in epidemics and, during the period of the survey, two winter epidemics occurred, both reaching peaks in November. The great majority of virus isolations occurred between October and March during these 2 years. However, in other months of the year, virus could still be isolated occasionally. 
TABLE 1. Frequency of RS virus isolations at various ages

\begin{tabular}{lcccrr}
\hline & $0-5$ months & $6-11$ months & $1-4$ years & $5-14$ years & All ages \\
\hline No. of RS virus isolations & 165 & 35 & 49 & 7 & 256 \\
Total no. of specimens & 682 & 374 & 1075 & 287 & 2418 \\
Isolation rate & 23.9 & $9 \cdot 3$ & 4.4 & 2.4 & 10.5 \\
\hline
\end{tabular}

TABLE 2. The frequency of occurrence of RS virus in the clinical categories by age

\begin{tabular}{lccccc}
\hline & URTI & Croup & Bronchitis & Bronchiolitis & Pneumonia \\
\hline 0-5 months & $9(15)$ & 0 & $35(23 \cdot 3)$ & $85(38 \cdot 3)$ & $36(23 \cdot 3)$ \\
6-11 months & $4(4 \cdot 4)$ & $1(2 \cdot 7)$ & $15(18 \cdot 3)$ & $7(15 \cdot 2)$ & $8(9 \cdot 3)$ \\
1-4 years & $19(4 \cdot 7)$ & $5(3 \cdot 5)$ & $9(5 \cdot 1)$ & $3(9 \cdot 7)$ & $13(6)$ \\
5-14 years & $2(2 \cdot 2)$ & 0 & $1(2 \cdot 3)$ & 0 & $4(4 \cdot 7)$ \\
\hline Total all ages & $34(5 \cdot 3)$ & $6(2 \cdot 6)$ & $60(13)$ & $95(31 \cdot 4)$ & $61(11 \cdot 2)$ \\
\hline
\end{tabular}

Figures in parentheses are isolation rates.

Clinical features. Table 3 records the clinical features which were present in 249 RS virus infections. Cough was a feature common to all the younger children with acute respiratory illness including those caused by RS virus; the frequency of dyspnoea, wheezing, chest recession and the relative frequency compared with other respiratory infections of pulmonary distension and increased translucency seen on radiographs should be noted. These features illustrate that $\mathrm{RS}$ virus can cause a severe obstructive illness of the lower respiratory tract in infants.

\section{General practitioner survey}

Isolation rate. The picture of RS virus as seen in hospital has been described and any differences between it and the general practice survey must be noted. 3966 patients were sampled for the general

TABLE 3. Clinical features in respiratory syncytial virus infections

\begin{tabular}{lcccc}
\hline & $\begin{array}{c}0-5 \\
\text { months }\end{array}$ & $\begin{array}{c}6-11 \\
\text { months }\end{array}$ & $\begin{array}{c}1-4 \\
\text { years }\end{array}$ & All ages \\
\hline No. of isolations & 165 & 35 & 49 & 249 \\
\hline Nasal discharge & 56 & 67 & 46 & 55 \\
Red pharynx & 45 & 54 & 56 & 49 \\
Cough & 97 & 98 & 75 & 93 \\
Dyspnoea & 78 & 50 & 51 & 68 \\
Cyanosis & 21 & 11 & 14 & 18 \\
Wheezing & 76 & 72 & 32 & 66 \\
Chest recession & 60 & 39 & 26 & 49 \\
Pulmonary distension & 32 & 28 & 10 & 28 \\
Rhonchi & 68 & 59 & 35 & 61 \\
Rales & 53 & 54 & 30 & 47 \\
Radiographs- & & & & \\
$\quad$ incr. transl. & 26 & 19 & 7 & 21 \\
Radiographs-shadows & 23 & 41 & 32 & 31 \\
Fever & 60 & 85 & 79 & 67 \\
Convulsions & 2 & 4 & 21 & 6 \\
Vomiting & 52 & 46 & 37 & 49 \\
\hline
\end{tabular}

practice survey, but from them only thirty-six RS viruses were isolated, an isolation rate of $0.9 \%$. This rate is misleading because the general practitioner survey included patients up to and greater than the age of 45 years. There were, however, 985 children of 4 years of age or less who were investigated for acute respiratory infection, twenty-nine of these had RS virus infection. This is an isolation rate of $2.9 \%$. For the same age group in the hospital survey, the isolation rate was $11.6 \%$.

In the general practitioner survey, pneumonia and bronchiolitis were classified together and the isolation rate of RS virus in these conditions was $19.8 \%$. This can be compared with the $23.5 \%$ for patients of the same age who were classified separately as bronchiolitis and pneumonia in the hospital survey. The lower rate of RS virus isolations in general practice might be due to greater difficulties in arranging for the transport of specimens from patients to laboratory. It would be unreasonable to draw the conclusion from the evidence presented that RS virus caused little of the milder respiratory syndromes in general practice and only bronchiolitis and pneumonia.

The clinical picture. Thirty-six RS virus isolations were associated mainly with pneumonia and bronchiolitis in which group seventeen cases occurred. There were also five influenza-like illnesses. The other isolations were distributed among the other clinical categories. The clinical features most frequently observed were cough, coryza, wheeze and fever.

\section{Sensitive cell lines}

It has long been known that HeLa and HEp 2 cells are the most suitable cell lines for the isolation of RS virus (Peacock \& Clarke, 1961). The hospital 
study confirmed this in full. It also illustrated that RS virus could be isolated on monkey kidney cells and human diploid cells on occasions. These cell lines are probably less sensitive and the cytopathic effect characteristic of RS virus on continuous cell lines is not easily recognizable (see Poole \& Tobin, Table 3, this symposium).

\section{Day of isolation}

The majority of specimens were taken on the third day after onset of illness in the hospital survey. It was noted that there was an increase in the isolation rate of RS virus from 4 to $5 \%$ during the first 2 days of illness to $15 \%$ on the fourth and fifth days in contrast to the other viruses which either decreased or remained constant.

\section{Deaths}

During the course of the survey twenty-two deaths occurred and four of them were associated with RS virus. This almost certainly underestimated the role of RS virus, as many of the investigations were delayed and some incomplete.

\section{Discussion}

This survey has confirmed the importance of RS virus as a causal agent of severe lower respiratory infection of infancy and has also been shown to be the major cause of the clinical condition of bronchiolitis. Disappointing features were the relatively low rate of virus isolation. This was especially true for the general practice survey, where possible false conclusions might be reached if this rate was accepted at face value. One of the urgent needs at the moment for RS virus infection is to know what fraction of total respiratory illness in the community is represented by hospital admissions. The extent of RS virus infection in the community will be a factor in determining how much effort should be expended in research into the prevention of RS virus infection.

These two surveys were embarked upon before newer techniques were available to augment the then well-tried cultural methods. The isolation techniques of these surveys were based on throat swabs only. Since 1968, nasopharyngeal secretions taken at the same time as cough swabs have been the specimens used for respiratory virus investigations in Newcastle. Figures first published in 1970 (McQuillin, Gardner \& Sturdy, 1970) showed that secretions were approximately $15 \%$ more effective than cough swabs.

The introduction of nasopharyngeal secretions as a method of taking specimens for the isolation of virus led to the use of cell deposits in these secretions for the rapid diagnosis of RS virus infection. These cell deposits were stained by the indirect fluorescent antibody technique and examined under ultra- violet light; specific staining of RS virus antigen could clearly be seen in the respiratory epithelial cells and appeared as inclusion-like bodies and fine particles in the cytoplasm of the cells. Table 4 illustrates the correlation of RS virus isolation and the diagnosis by immunofluorescence. Four failures by immunofluorescence were solely due to poor specimens with too few respiratory cells. The twentyfive positive specimens without parallel virus isolations were all in patients who had been ill for longer than $\mathbf{5}$ days, some for as long as $\mathbf{1 4}$ days. Previous work has shown that immunofluorescence lasts longer than virus infectivity (Gardner, McQuillin \& McGuckin, 1970) and these twenty-five specimens represent the increased sensitivity of the immunofluorescence method of diagnosis in the convalescent stage of the illness to virus culture.

Table 5 illustrates the effect these newer techniques have had on the diagnosis of respiratory virus infection of 1046 consecutive admissions of children under the age of 1 to Newcastle Hospitals. RS virus appears to be the causative agent in over $75 \%$ of children with bronchiolitis and a virus cause can be found in a total of $82 \%$ with this condition. These figures again emphasize the importance of RS virus infection, especially in children under the age of 1 . If the yearly figures of Newcastle apply to the country as a whole, it would represent approximately 30,000 35,000 admissions per year of children with $R S$ virus infection and these admissions would be concentrated into a 3-4 month period.

Further studies have shown that RS virus may infect infants still in maternity homes but producing only mild illness (Neligan et al., 1970) and is a cause of severe illness in ward cross-infection (Ditchburn,

TABLE 4. Correlation between RS virus isolations and immunofluorescence: September 1969 to March 1972

\begin{tabular}{ccccc}
\hline \multicolumn{2}{c}{ RS virus isolated } & & \multicolumn{2}{c}{ RS virus not isolated } \\
\cline { 1 - 2 } \cline { 5 - 6 } FA positive & FA negative & & FA positive & FA negative \\
\hline 419 & 4 & & 25 & 1138 \\
\hline
\end{tabular}

TABLE 5. Clinical categories and viruses in 1046 children under 1 year of age April 1969 to April 1972

\begin{tabular}{lcccc}
\hline $\begin{array}{l}\text { Clinical } \\
\text { category }\end{array}$ & $\begin{array}{c}\text { Total no. } \\
\text { of patients }\end{array}$ & $\begin{array}{c}\text { RS } \\
\text { virus }\end{array}$ & $\begin{array}{c}\text { All other } \\
\text { viruses }\end{array}$ & $\begin{array}{c}\text { Total } \\
\text { viruses }\end{array}$ \\
\hline Bronchiolitis & 401 & 301 & 30 & 331 \\
Pneumonia & 99 & 22 & 24 & 46 \\
\hline Bronchitis & 195 & 61 & 40 & 101 \\
Croup & 29 & 2 & 19 & 21 \\
URTI & 322 & 60 & 81 & 141 \\
\hline Total & 1046 & 446 & 194 & 640 \\
\hline
\end{tabular}


McQuillin, Gardner \& Court, 1971). The seriousness of RS virus infection is also emphasized by the deaths which it causes. The delay between death and autopsy makes this virus difficult to isolate but immunofluorescence may be a help under these circumstances. The virus has been shown to be the most frequent virus found both in acute respiratory deaths and in approximately one-quarter to onethird of sudden and unexpected deaths in infancy (Gardner et al., 1967; Aherne et al., 1970).

This communication has attempted to show how our knowledge of this virus has evolved through various national and local surveys and also to indicate its importance in paediatric medicine.

\section{References}

Aherne, W., Bird, T., Court, S.D.M., Gardner, P.S. \& MCQuillin, J. (1970) Pathological changes in virus infections of the lower respiratory tract in children. Journal of Clinical Pathology, 23, 7.

ANDREW, J.D. \& GARDNER, P.S. (1963) Occurrence of respiratory syncytial virus in acute respiratory diseases in infancy. Briish Medical Journal, 2, 1447.

Beem, M., Wright, F.H., Hamre, D., Egerer, R. \& Oehme, M. (1960) Association of the chimpanzee coryza agent with acute respiratory disease in children. New England Journal of Medicine, 263, 523.

Chanock, R.M. \& Finberg, L. (1957) Recovery from infants with respiratory illness of a virus related to Chimpanzee Coryza Agent (C.C.A.). II. Epidemiologic aspects of infection in infants and young children. American Journal of Hygiene, 66, 291.

Chanock, R.M., KIm, H.W., Vargosko, A.J., Deleva, A., Johnson, K.M., Cumming, C. \& PARrott, R.H. (1961) Respiratory syncytial virus. I. Virus recovery and other observations during 1960 outbreak of bronchiolitis, pneumonia, and minor respiratory diseases in infancy. Journal of the American Medical Association, 176, 647.
Ditchburn, R.K., McQuillin, J., Gardner, P.S. \& Court, S.D.M. (1971) Respiratory syncytial virus in hospital cross-infection. Briish Medical Journal, 3, 671.

Elderkin, F.M., Gardner, P.S., TURK, D.C. \& White, A.C. (1965) Aetiology and management of bronchiolitis and pneumonia in childhood. British Medical Journal, $2,722$.

GARDNER, P.S. (1968) Virus infection and respiratory disease of childhood. Archives of Disease in Childhood, 43, 629.

GARDNer, P.S., McQuillin, J. \& MCGuckin, R. (1970) The late detection of respiratory syncytial virus in cells of respiratory tract by immunofluorescence. Journal of Hygiene, 68, 575.

Gardner, P.S., Turk, D.C., Aherne, W.A., Bird, T., HoldawaY, M.D. \& CourT, S.D.M. (1967) Deaths associated with respiratory tract infection in childhood. British Medical Journal, 4. 316.

holzel, A., Parker, L., Patterson, W.H., Cartmel, D., White, L.L.R., Purdy, R., Thompson, K.M. \& ToBIN, J.O'H. (1965) Virus isolations from throats of children admitted to hospital with respiratory and other diseases, Manchester, 1962-64. Briish Medical Journal, 1, 614.

Holzel, A., Parker, L., Patterson, W.H., White, L.L.R., Thompson, K.M. \& ToBin, J.O'H. (1963) The isolation of respiratory syncytial virus from children with acute respiratory disease. Lancet, i, 295.

McClelland, L., Hilleman, M.R., Hamparian, V.V., Ketler, A., Reilly, C.M., CoRnfeld, D. \& Stokes, J., JR (1961) Studies of acute respiratory illnesses caused by respiratory syncytial virus. II. Epidemiology and assessment of importance. New England Journal of Medicine, 264, 1169.

MCQuillin, J., Gardner, P.S. \& Sturdy, P.M. (1970) The use of cough/nasal swabs in the rapid diagnosis of respiratory syncytial virus infection by the fluorescent antibody technique. Journal of Hygiene, 68, 283.

Morris, J.A., Blount, R.E., JR \& SAVAGe, R.E. (1956) Recovery of cytopathogenic agent from chimpanzees with coryza. Proceedings of the Society for Experimental Biology and Medicine, $92,544$.

Neligan, G.A., Steiner, H., Gardner, P.S. \& McQuillin, J. (1970) Respiratory syncytial virus infection of the newborn. British Medical Journal, 2, 146.

Peacock, D.B. \& Clarke, S.K.R. (1961) Respiratory syncytial virus in Britain. Lancet, ii, 466. 